\title{
Hydrochemistry and Environmental Isotope Characteristics of Groundwater in the Kashgar Delta Area, Xinjiang, China
}

\author{
Xing Wei ${ }^{1,2}$, Jinlong Zhou ${ }^{1,2, *}$, Yinzhu Zhou ${ }^{3, * *}$, Yanyan Zeng ${ }^{1,2}$, and Yunfei Chen ${ }^{1,2}$ \\ ${ }^{1}$ College of Water Conservancy and Civil Engineering, Xinjiang Agricultural University, Urumqi, \\ 830052, China \\ ${ }^{2}$ Xinjiang Hydrology and Water Resources Engineering Research Center, Urumqi, 830052, China \\ ${ }^{3}$ Key Laboratory of Drinking Water Science and Technology, Research Center for Eco- \\ Environmental Sciences, Chinese Academy of Sciences, Beijing 100049, P.R.China
}

\begin{abstract}
The hydrochemistry and isotope characteristics of groundwater of different geomorphological types in the Kashgar Delta in Xinjiang, China were studied using isotopic analyses. Results showed that groundwater in the study area was mainly recharged by precipitation, and that groundwater ions were mainly affected by weathering-leaching of rock salt and evaporite as well as cation exchange and adsorption. The hydrochemical type of phreatic water in the alluvial-proluvial gravel plain on the piedmont slope was mainly $\mathrm{SO}_{4} \cdot \mathrm{Cl}-\mathrm{Na} \cdot \mathrm{Ca}$ type, with an average age of 28a. The phreatic water in the fluvial plain had shallow buried depth and intense evaporation. The hydrochemical type of phreatic water varied from $\mathrm{SO}_{4} \cdot \mathrm{Cl}-\mathrm{Na} \cdot \mathrm{Mg}$ type to $\mathrm{Cl}-\mathrm{Na}$ type, with an average age of $99 \mathrm{a}$. Along the groundwater flow path eastward, confined water in the fluvial plain experienced gradually more intense cation exchange and stronger adsorption. The major hydrochemical type of which was the $\mathrm{SO}_{4} \cdot \mathrm{Cl}-\mathrm{Na}$ type, with an average age of 30405 a.
\end{abstract}

\section{Introduction}

The Kashgar Delta area in Xinjiang, China is located in the Eurasia hinterland and the southwest of Xinjiang. The study area is surrounded by mountains in the south, north and west. There is a semi-closed delta basin in the center. The area belongs to the "qualityinduced water shortage" area with special and fragile water and ecological environment.

As an effective method in hydroscience research, hydrochemistry and isotopes were widely used in the studies investigating groundwater origin [1], age [2], circulation [3] and pollution [4]. In this study, hydrochemistry and isotope characteristics of groundwater in the Kashgar Delta region were analyzed through hydrochemistry and isotopes, which provide scientific evidence for rational exploitation and utilization of the water resources in this area.

\footnotetext{
* Corresponding author: zjzhouj1@163.com

** Correspondence to: yinzhu_zhou@qq.com (YZ Zhou)
} 


\section{Materials and methods}

412 groundwater samples (including 138 phreatic water samples and 274 confined water samples) were collected for hydrochemistry analysis. 285 groundwater samples (including 252 phreatic water samples and 33 confined water samples) were collected for $\mathrm{D}$ and ${ }^{18} \mathrm{O}$ isotope analysis. 101 groundwater samples (including 72 phreatic water samples and 29 confined water samples) were collected for ${ }^{3} \mathrm{H}$ isotope analysis. 80 groundwater samples (including 56 phreatic water samples and 24 confined water samples) were collected for ${ }^{14} \mathrm{C}$ isotope analysis. The distribution of sampling points was shown in the Fig.1.

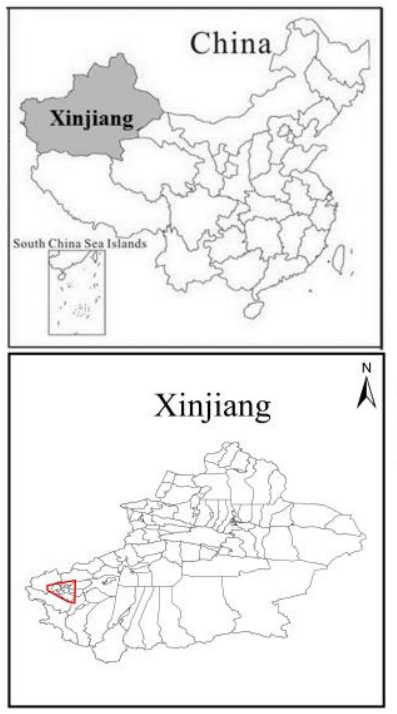

Legend

Wlas Alluvial-proluvial gravel plain on the piedmost slope Fluvial plain

Research area $76^{\circ} \mathrm{O}^{\prime} \mathrm{O}^{\prime \prime} \mathrm{E}$

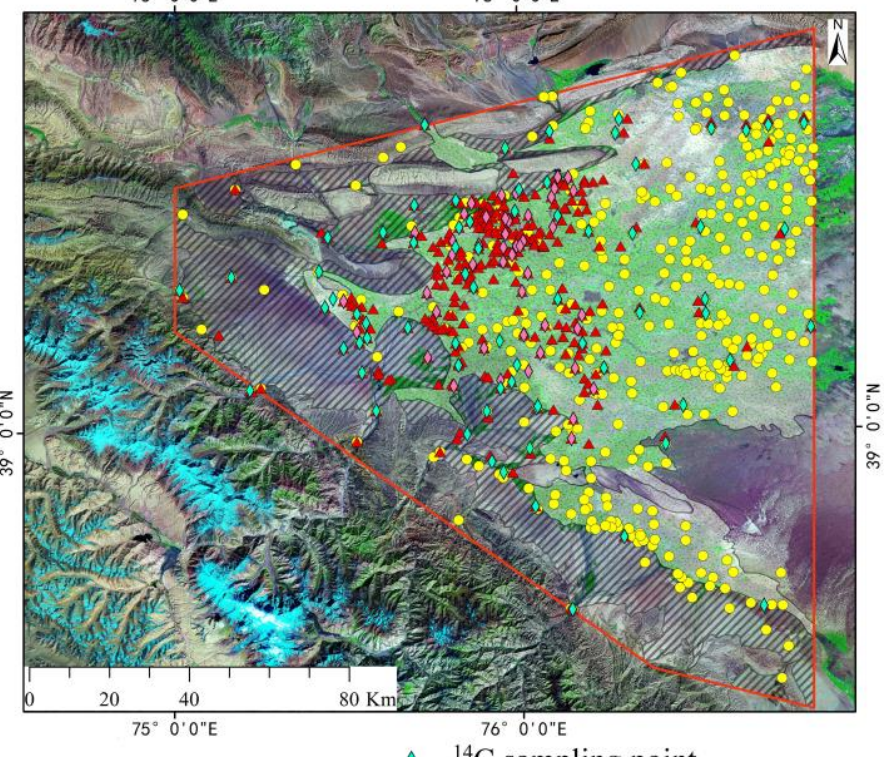

${ }^{14} \mathrm{C}$ sampling point

$\checkmark \quad{ }^{3} \mathrm{H}$ sampling point

- D、 ${ }^{18} \mathrm{O}$ sampling point

- Hydrochemistry sampling point

Fig. 1. Location of Sampling Point in the Study Area.

\section{Results and analysis}

\subsection{Hydrochemical characteristics and influencing factors}

Geomorphological factors have an important influence on hydrochemical evolution [5]. Phreatic water in the alluvial-proluvial gravel plain on the piedmont slope in the study area was mainly $\mathrm{SO}_{4} \cdot \mathrm{Cl}-\mathrm{Na} \cdot \mathrm{Ca}$ type. Phreatic water in the fluvial plain varied from $\mathrm{SO}_{4} \cdot \mathrm{Cl}-$ $\mathrm{Na} \cdot \mathrm{Mg}$ type to $\mathrm{Cl}-\mathrm{Na}$ type along the groundwater flow path. Confined water in the fluvial plain was mainly $\mathrm{SO}_{4} \cdot \mathrm{Cl}-\mathrm{Na}$ type.

As shown in Fig. 2(a), most of the sampling points fell above the $\gamma\left(\mathrm{Na}^{+}\right) / \gamma\left(\mathrm{Cl}^{-}\right)$ $=1: 1$ line, indicating that $\mathrm{Na}^{+}$and $\mathrm{Cl}^{-}$were mainly derived from rock salt leaching. In addition, cation exchange and adsorption may also cause $\mathrm{Na}^{+}$desorption. $\gamma\left(\mathrm{Ca}^{2+}\right) / \gamma\left(\mathrm{SO}_{4}{ }^{2-}\right)$ ratio was generally less than 1 (Fig. 2 b), which indicated that groundwater $\mathrm{Ca}^{2+}$ and $\mathrm{SO}_{4}{ }^{2-}$ concentrations were mainly affected by evaporite weathering and leaching, as well as exchange and adsorption of $\mathrm{Na}^{+}$and $\mathrm{Ca}^{2+}$ ions. Groundwater $\gamma\left(\mathrm{Mg}^{2+}+\mathrm{Ca}^{2+}-\mathrm{SO}_{4}{ }^{2-}-\mathrm{HCO}_{3}{ }^{-}\right)$ 
had a strong negative correlation with $\gamma\left(\mathrm{Na}^{+}-\mathrm{Cl}^{-}\right)\left(\mathrm{R}^{2}=0.9089\right)$ (Fig. 2c) with the ratio about -1 , which indicated that major groundwater ions were affected by cation exchange and adsorption. The relationship between $\gamma\left(\mathrm{Na}^{+}\right) / \gamma\left(\mathrm{Na}^{+}+\mathrm{Mg}^{2+}+\mathrm{Ca}^{2+}\right)$ and $\gamma\left(\mathrm{Cl}^{-}\right)$(Fig. 2d) suggested that along the groundwater flow path eastward, the burial depth of phreatic water in the fluvial plain (Zone I) became smaller. Groundwater $\mathrm{Na}^{+}$and $\mathrm{Cl}^{-}$concentrations were relatively high, influenced by evaporation. With the decrease of particle sizes and increase of clay mineral contents in the confined aquifer medium, as well as the increase of cation exchange and adsorption, the $\mathrm{Na}^{+}$adsorbed on mineral surfaces was exchanged by groundwater $\mathrm{Ca}^{2+}$ and $\mathrm{Mg}^{2+}$. This resulted in groundwater that had a greater $\mathrm{Na}^{+}$ concentration than $\mathrm{Cl}^{-}$concentration.
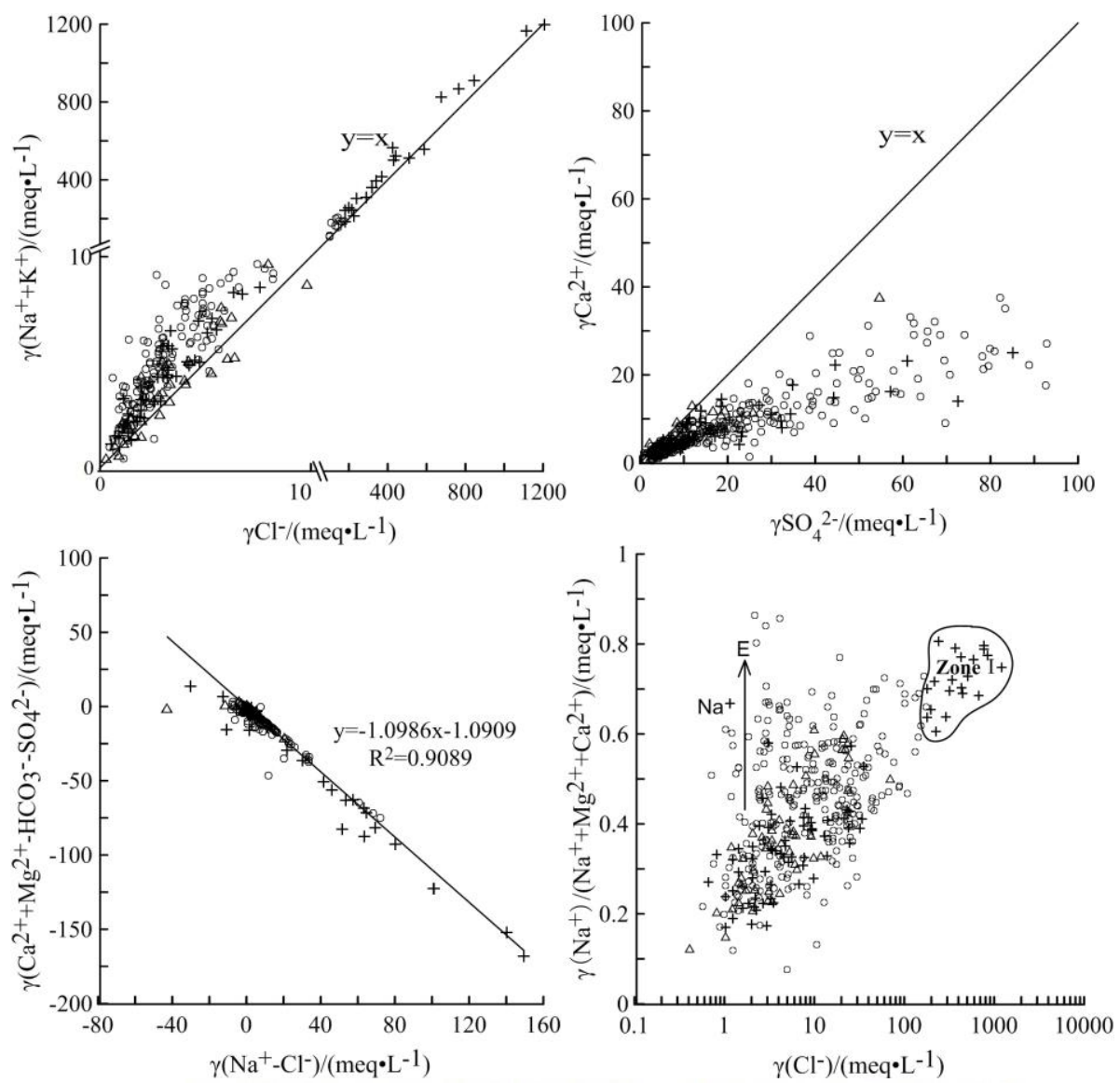

$\triangle$ Phreatic water in the alluvial-proluvial gravel plain on the piedmont slope

+ Phreatic water in the fluvial plain

Confined water in the fluvial plain

Fig. 2. Groundwater Ion Relationship between $\mathrm{Na}^{+}$and $\mathrm{Cl}^{-}(\mathrm{a}), \mathrm{Ca}^{2+}$ and $\mathrm{SO}_{4}{ }^{2-}(\mathrm{b}),\left(\mathrm{Ca}^{2+}+\mathrm{Mg}^{2+}-\right.$ $\left.\mathrm{HCO}_{3}^{-}-\mathrm{SO}_{4}^{2-}\right)$ and $\left(\mathrm{Na}^{+}-\mathrm{Cl}^{-}\right)(\mathrm{c}),\left(\mathrm{Na}^{+} / \mathrm{Na}^{+}+\mathrm{Mg}^{2+}+\mathrm{Ca}^{2+}\right)$ and $\mathrm{Cl}^{-}(\mathrm{d})$.

\subsection{Groundwater $D$ and ${ }^{18} \mathrm{O}$ isotope characteristics}

Isotopic compositions of $\mathrm{D}$ and ${ }^{18} \mathrm{O}$ in groundwater varied among different geomorphological types in the study area. The average $\delta \mathrm{D}$ value of phreatic water in the alluvial- proluvial gravel plain on the piedmont slope, phreatic water in the fluvial plain, 
and confined water in the fluvial plain were $-73.0 \%$ o, $-79.9 \%$ and $-77.1 \%$, respectively. The average $\delta^{18} \mathrm{O}$ values were $-10.52 \%$, $-11.09 \%$ and $-10.70 \%$, respectively. As shown in Fig. 3 , groundwater $\mathrm{D}$ and ${ }^{18} \mathrm{O}$ compositions in the study area were mostly located below the local meteoric water line [6]. This indicated that the recharge sources of groundwater experienced intensive evaporation, which resulted in the enrichment of $\mathrm{D}$ and ${ }^{18} \mathrm{O}$. Phreatic water in the fluvial plain was greatly influenced by evaporation, which often occurred in closed basins in arid areas [7].

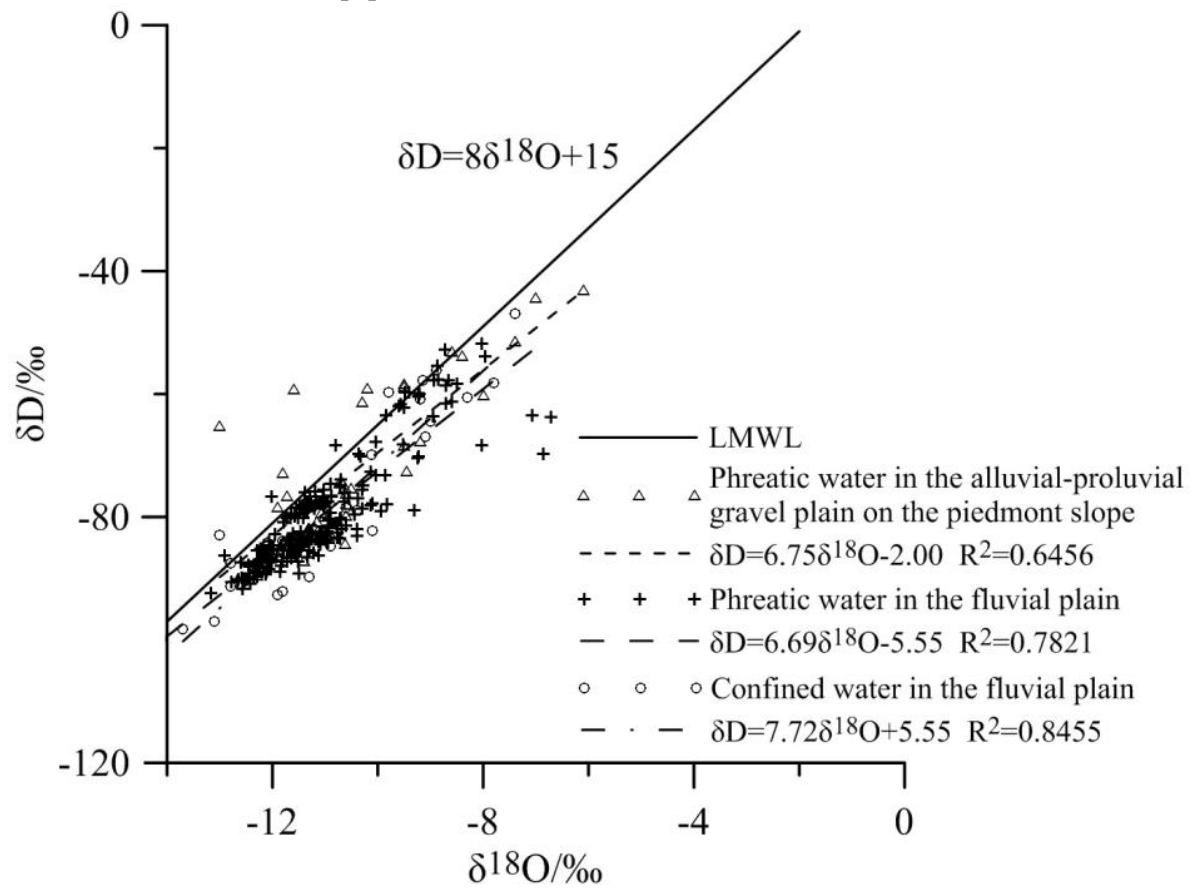

Fig. 3. Relationship between $\delta \mathrm{D}$ and $\delta^{18} \mathrm{O}$ values in groundwater.

\section{$3.3^{3} \mathrm{H}$ and ${ }^{14} \mathrm{C}$ in groundwater dating}

The ${ }^{3} \mathrm{H}$ and ${ }^{14} \mathrm{C}$ compositions in groundwater varied among different geomorphological types which had different groundwater ages. ${ }^{3} \mathrm{H}$ was mainly used to date young/modern groundwater ages within 50a while ${ }^{14} \mathrm{C}$ was mainly used to date old groundwater ages over 2000a. Therefore, ${ }^{14} \mathrm{C}$ was used to date groundwater ages $>50$ a. For groundwater ages $<$ $50 \mathrm{a},{ }^{3} \mathrm{H}$ was used in the 'total mixing model' for groundwater dating [8], while for groundwater ages $>50 \mathrm{a},{ }^{14} \mathrm{C}$ was used in the "Tamers model" for groundwater dating [9]. Results showed that phreatic water ages in the accumulation alluvial plain on the piedmont slope ranged between 6 and 50a (average age of 28a), phreatic water ages in the fluvial plain ranged between 8 and 389a (average age of 99a), and confined water ages in fluvial plain ranged between 5186 and 34578a (average age of 30405a).

\section{Conclusions}

(1) Groundwater ion composition in the Kashgar Delta area in Xinjiang, China was mainly affected by weathering-leaching of rock salt and evaporite as well as the cation exchange and adsorption. Phreatic water in the alluvial-proluvial gravel plain on the piedmont slope was mainly $\mathrm{SO}_{4} \cdot \mathrm{Cl}-\mathrm{Na} \cdot \mathrm{Ca}$ type. Along groundwater flow path eastward, 
with smaller burial depth and more intensive evaporation, phreatic water in fluvial plain (Zone I) varied from $\mathrm{SO}_{4} \cdot \mathrm{Cl}-\mathrm{Na} \cdot \mathrm{Mg}$ type to $\mathrm{Cl}-\mathrm{Na}$ type. With more intensive cation exchange and absorption, the confined groundwater was mainly $\mathrm{SO}_{4} \cdot \mathrm{Cl}-\mathrm{Na}$ type.

(2) The slope of $\delta \mathrm{D}-\delta^{18} \mathrm{O}$ was slightly smaller than that of local meteoric water line, indicating that groundwater was mainly recharged by precipitation and affected by evaporation during the recharge process. Phreatic water in the fluvial plain was greatly influenced by evaporation.

(3) The average age of phreatic water in the alluvial-proluvial gravel plain on the piedmont slope in the study area was 28a. The average age of phreatic water in the fluvial plain was 99a and that of confined water in the fluvial plain was 30405a.

Acknowledgements. The research was funded by the National Natural Science Foundation of China (NSFC) project 'Research on Groundwater Salinization Mechanism in Kashgar Area of Xinjiang' (41662016) and the Water Conservancy Engineering Foundation Project (xjslgcgfxk20161103), the peak discipline in the key discipline construction of the $13^{\text {th }}$ Five-Year Plan of Xinjiang Autonomous Region.

\section{References}

1. N.M Asmael, F Huneau, E Garel, H Celle-Jeanton, P.L Coustumer, A Dupuy, S Hamid. Arab J Geosci., 8, 12 (2015)

2. K Hadi, U.S Kumar, M.A Senafy, H Bhandary. Environ Earth Sci., 74 (2016)

3. C Herrera, E Custodio, G Chong, L.J Lamban, R Riquelme, et al. Sci Total Environ., 541 (2016)

4. R Li, Q Xiao, W Liu, F Guo, M.C Pan, S Yu. Environ Sci., 36, 8 (2015) (in Chinese)

5. J Shao, Y Li, W.K Wang, G.C Hou. Hydroge \& Eng Geol., 43, 4 (2016) (in Chinese)

6. W.X Wang, R.J Wang, W.P Li, X.L Yin, C.L Liu. Hydroge \& Eng Geol., 40, 4 (2013) (in Chinese)

7. Q Yang, H.L Xiao, L.J Zhao, Y.G Yang, C.Z Li, L Zhao, L Yin. Hydrol Process, 25, 8 (2011)

8. Y.F Ruan, L.J Zhao, H.L Xiao, M.X Zhou, G.D Cheng. J Glaciol and Geocryol, 37, 3 (2015) (in Chinese)

9. F Liu, Y.L Cui, G Zhang, F.Q Gen, J Liu. Geosci, 28, 6 (2014) (in Chinese) 